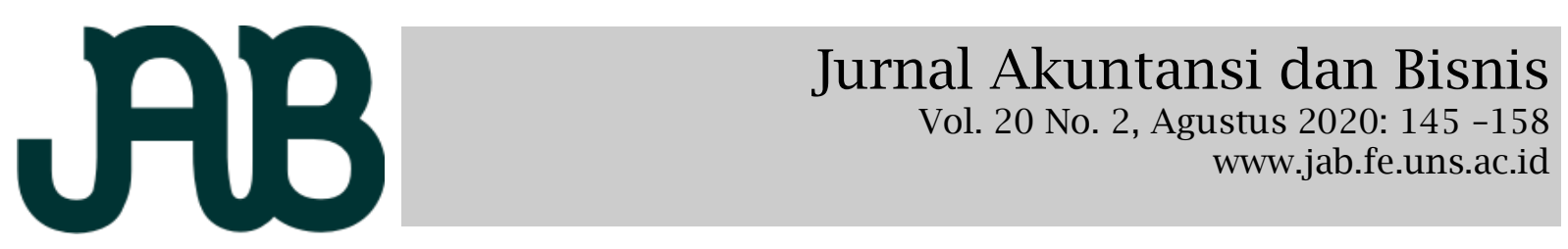

\title{
THE INFLUENCE OF ACCOUNTING KNOWLEDGE IN MODERATING RELATIONSHIP BETWEEN UNDERSTANDING AND SOCIALIZATION OF TAX TO MSMES TAX COMPLIANCE
}

\author{
APRIANI KARTIKA RAHAYU \\ ICUK RANGGA BAWONO (icuk.bawono@unsoed.ac.id) \\ YUDHA ARYO SUDIBYO
}

Accounting Department, Economic and Bussiness Faculty, Jenderal Soedirman University, Indonesia

\begin{abstract}
A B S T R A C T
This research aims to analyze the understanding and socialization of taxation on tax compliance of MSMEs. This research also aims to analyze the influence of understanding of accounting in moderating the relationship of understanding and socialization of taxation on tax compliance of MSMEs. Samples were determined by the stratified cluster sampling method. The number of respondents is 151 MSMEs owners/managers/actors in sectors of the trade, hotel, and restaurant. This study uses the Structural Equation Model (SEM) to analyze the purposes of this research. Effect size analysis is used to determine how big is the moderation effect from the variable of accounting knowledge. Through path analysis, this research states that taxation understanding and socialization have a significant positive effect on tax compliance of MSMEs. Then, accounting knowledge has a significant and weakening effect on moderating the relationship between taxation understanding and tax compliance of MSMEs. Meanwhile, accounting knowledge has not been proven to moderate the relationship between tax socialization on tax compliance of MSMEs.

Keywords: SMEs, accounting knowledge, understanding of taxation, socialization of taxation, tax compliance
\end{abstract}

Penelitian ini bertujuan untuk menganalisis pemahaman dan sosialisasi perpajakan terhadap kepatuhan pajak UMKM. Penelitian ini juga bertujuan untuk menganalisis pengaruh pemahaman akuntansi dalam memoderasi hubungan dari pemahaman dan sosialisasi perpajakan terhadap kepatuhan pajak UMKM. Sampel ditentukan menggunakan metode stratified cluster sampling. Jumlah responden adalah 151 pemilik/manajer/pelaku UMKM yang bergerak pada sektor perdagangan, hotel, dan restoran. Penelitian ini menggunakan Structural Equation Model (SEM) untuk menganalisis tujuan penelitian ini. Analisis ukuran efek digunakan untuk menentukan besar pengaruh moderasi dari variabel pemhaman akuntansi. Melalui analisis jalur, hasil penelitian ini menyatakan bahwa pemahaman dan sosialisasi perpajakan berpengaruh positif signifikan terhadap kepatuhan pajak UMKM. Kemudian, pemahaman akuntansi berpengaruh signifikan dan bersifat melemahkan dalam memoderasi hubungan pemahaman perpajakan pada kepatuhan pajak UMKM. Sementara itu, pemahaman akuntansi tidak terbukti memoderasi hubungan sosialisasi pajak pada kepatuhan pajak UMKM.

Kata kunci: UMKM, pemahaman akuntansi, pemahaman perpajakan, sosialisasi perpajakan, kepatuhan pajak

\section{INTRODUCTION}

As one of the government revenues, in 2018 , tax contributed $78.3 \%$ or equivalent to Rp1,521.4 trillion of the Total Annual State Budget (APBN) in Indonesia (Ministry of Finance, 2019). An amount of tax revenue in 2018 indicates that tax becomes the dominant revenue for the State treasury fund. Every individual or entity that has fulfilled subjective and objective require- ments under Article 2 of Law Number 36 the Year 2008 will be assumed to comply with taxation regulations. Even Micro, Small, and Medium Enterprises (MSMEs) that receive income from business activities also have the same tax rights and obligations as other taxpayers if they already meet the requirements.

Data from the Ministry of Cooperatives and Small and Medium Enterprises 
(2020a, 2020d, 2020b, 2020c) shows that in 2014-2018 the number of registered MSME units in Indonesia continues to increase from year to year. In 2018 there were 64.19 million of MSME units. Besides, in 2018 MSMEs succeeded in contributing Rp8,573.8 trillion or lead a $61.1 \%$ share to Indonesian GDP (Ministry of Cooperatives and Small and Medium Enterprises, 2020d). Data from the Department of Manpower, Cooperatives, and Small and Medium Enterprises in Banyumas Regency in 2019 showed as many as 42,355 or $50.17 \%$ of MSME units were engaged in the trade, hotel, and restaurant sectors. Meanwhile, the trade sector in Banyumas Regency became the main focus of the economy and ranked 3rd in contributing $4.4 \%$ of economic growth in Central Java (Suara Merdeka, 2018).

Several government policies were launched to balance the tax compliance of SMEs to the contribution of MSMEs in the national economy. In 2008, the government approved a taxation policy regarding special income tax (PPh) rates for MSMEs. However, this policy was limited to business entities. The policy was stated in Law Number 36 the Year 2008 concerning Income Tax in Article $31 \mathrm{E}$ (1). In addition, the government issued Government Regulation No. 23 the Year 2018 that businesses that have a gross circulation of less than Rp4.8 billion is subject to a final income tax of $0.5 \%$ of the gross business circulation.

Although the government tried to provide several tax policies to MSMEs, of more than 60 million MSME units registered in Indonesia in 2018, only around $2.5 \%$ or approximately 1.5 million MSME units reported taxes (Noor, 2018). Based on data from Tax Office KPP Pratama Purwokerto published in February 2019, the tax gain of the Banyumas Regency from 2013 to 2017 has fluctuated and none of them reached the target. Then, there was an increase in the number of Tax Letter of Notification submissions in 2017 by 954 late submitted to Tax Office KPP Pratama Purwokerto from the previous year of only 770 out of the total 23,380 required to report non-employee of individual taxpayers and institution taxpayers. It is mandatory for non-employee individual and agency taxpayers such as casual workers, employers, and agencies to report their taxes. The small percentage of MSME tax compliance indicates that there is still considerable potential extracted from the MSMEs sector's tax.

Several factors make the MSMEs sector have low compliance to run an errand as a taxpayer. Previous studies explain that adequate tax knowledge will make someone aware of his tax obligations (Mukhlis, Utomo and Soesetio, 2015). In contrast, Akbar's research (2015) states that taxpayer understanding does not influence the extent to which MSMEs can comply with their tax obligations. In addition, Kwok and Yip (2018) stated that taxpayers would be more capable and ready to comply with taxation rules if they understand what they have to do. Tax socialization will encourage MSMEs to develop positive perceptions about the tax system's fairness when they learn how the tax system works. On the contrary, Cahyanti (2017) states that the taxation socialization and the financial condition of entrepreneurs do not affect MSME taxpayers' compliance. Then, even if income tax aspects are so simple to understand, it is almost impossible for entrepreneurs to know them without knowing accounting concepts (Sani and Habibie, 2018). However, Safitri (2018) states another opinion that there is no need for MSMEs who have a turnover of below Rp4.8 billion to understand accounting in order to be able to carry out tax obligations. Although researchers often use these variables to explain the tax compliance of MSMEs, it still shows a gap between them in the last five years.

Attribution theory by Fritz Heider in 1958 was used to explain individual behavior of internal or external causes. Furthermore, the Theory of Planned Behavior (TPB) by Ajzen in 1991 explained that attitudes toward behavior, subjective norms, and perceptions of behavioral control could influence one's intention to perform a behavior. Modified combinations of attribution and TPB theories explain how a person intends to perform one behavior after being influenced by internal and external factors. The theories have been modified to 
adjust field conditions and solve the theoretical problem suspected to be a problem of difference in result difference. Accounting knowledge as control behavior has been modified as a moderator variable because it is used as a basis in the initial calculation of income tax for MSMEs. The proper calculation will make them comply with tax materially. The insight of someone do a behavior, the perception of control over behavior is talk about the success level doing one behavior depends on his effort or other factors out of him. The level of difficulty in performing tax compliance behavior can also affect the success of the realization of tax compliance behavior. Related to MSMEs compliance with tax obligations, it's essential to know and trace problems that arise when almost all individual MSMEs taxpayers try to avoid their tax obligation, of course, MSMEs with institution form would not be forgotten.

Based on Article 28 (1) of Law Number 28 of 2007 concerning General Provisions and Tax Procedures, every personal taxpayer who runs a business or freelancer and taxpayers with institution form has to conduct bookkeeping for reported income validation purposes to Directorate General Tax (DGT). In particular terms, these personal taxpayers could only provide transaction recording. This recording and bookkeeping requirement is a control for DGT to make sure MSMEs report their true income. This term obligation becomes one obstacle that often makes MSMEs discouraged from doing tax obligations (Kusuma, 2018). When there is an error in the tax base's value, the tax calculated, paid, and reported will not correspond to the actual income tax that must be charged. Accounting knowledge makes it MSME taxpayers will easy to do tax obligations step by step. On the other hand, accounting knowledge makes MSMEs taxpayers aware that paying taxes can reduce a net business income, so they would not be doing tax obligations. Meanwhile, after someone knows about accounting matters on the socialization side, it could make it easy to receive information about calculating MSME income tax. On the other hand, knowing accounting could drive MSMEs antipathic and have passive respond with tax socialization.

Meanwhile, to comply with tax formally, taxpayers need to understand building their minds and being willing to pay a tax. This mind build and willingness could be coming from inner thought or outside pressure from the community. Inner thought of someone could build attitudes toward behavior for intention doing of something. This inner thought of MSMEs taxpayers proxied by an understanding of taxation. Understanding taxation will influence the assessment of the consequences that they will receive when performing a tax compliance behavior. MSMEs form in Indonesia tend to be dominated by personal management owned by individuals, and rarely found external parties that can interfere in its managerial. Personal judgment by MSMEs manager or owner would lead MSMEs into one decision making. Business needs can influence this decision, or it can be pressure from outside parties. It's different from an outside factor that pushes someone to comply with society's subjective norm for obeying some behavior. In this study, the subjective norm of MSMEs proxied by tax socialization. The tax socialization leads MSMEs taxpayers to comply with existing norms that paying taxes is the duty of every citizen. The tax socialization will affect one's views so that there is a motivation that compliant tax behavior is essential and a must for every citizen. Compared to the Theory of Reasoned Action (TRA), TPB is chosen because it could clearly explain factors that some individuals can not control by complying with one specific behavior.

Previous studies discuss the importance of tax understanding and tax socialization in shaping MSME's tax compliance behavior. However, there are still differences in research results in the recent ten years. Apart from the main things that affect MSME tax compliance, MSME accounting knowledge could be one factor that influences the number of business financial information that MSMEs can provide. This financial information can be obtained from recording and/or bookkeeping. Financial information is essential because it is used as a basis in the initial calculation 
of income tax for MSMEs. The problem from MSME actors' perspective regarding bookkeeping needs to be considered for the tax compliance behavior will be carried out by MSMEs. Even though accounting knowledge is an essential matter to a businessman to complete their understanding of taxation, there's no single research found accounting knowledge of MSMEs owner or manager becomes moderation variable when this research be held.

Unlike earlier research, this research analyses accounting knowledge of MSMEs as a moderating variable. This research modified the TPB framework to explain MSMEs tax compliance, and this study focuses on MSMEs around Banyumas Regency. The Banyumas Regency being chosen because data from KPP Pratama Purwokerto show there is a fluctuation of tax received in Banyumas Regency and taxpayers who late report their SPT increased from the year 2016 to 2017. Because of these phenomena and there is a research result gap, researchers held research entitled "The Influence of Accounting Knowledge in Moderating Relationship between Understanding and Socialization of Tax to MSMEs Tax Compliance". This research is held to prove the theoretical framework of this study.

\section{LITERATURE REVIEW AND HYPOTHESIS DEVELOPMENT}

\section{The Influence of Tax Understanding on MSMEs Tax Compliance}

Tax understanding refers to the process by which taxpayers become aware of tax laws and other tax-related information (Oladipupo and Obazee, 2016). In short, taxation understanding is a taxpayer's process in understanding tax information and rules to be aware of their rights and obligations in taxation. Attribution theory explains that someone gives meaning to a certain behavior, which can be caused by internal factors under someone's control. The understanding of tax matters could make someone do a certain assessment of the consequences of doing a behavior to comply with tax obligations. The consequence of this tax evaluation triggers taxpayers, especially MSMEs to conduct a certain behavior about tax. It is in harmonize with the attitude towards behavior variables in TPB. The MSME's shallow understanding of regarding taxation system makes many MSMEs do not understand the benefits they receive from taxation. This lack of understanding of tax knowledge will make MSMEs consider that compliance with tax obligations will not be beneficial for them in the future time so that there are still many who deliberately ignore their tax obligations. An inadequate understanding of taxation has led some MSMEs to develop a perception that current tax rules and mechanisms are considered complicated and difficult (Sudibyo, Purnomo and Bawono, 2017; Tatik, 2018). A research conducted by Mukhlis et al. (2015) explains that a higher level of tax knowledge will make people aware of their tax obligations. The same thing was conveyed in the research results of Oladipupo and Obazee (2016), Anwar and Syafiqurrahman (2016), and Wardani and Wati (2018), which state that a high level of tax understanding would increase tax compliance of MSMEs. Different result shows by Akbar's research (2015) states that taxpayer understanding does not influence the extent to which MSMEs can comply with their tax obligations.

H1: Understanding of taxation has a positive effect on MSMEs tax compliance

\section{The Influence of Tax Socialization on MSMEs Tax Compliance}

Socialization according to the Indonesian Dictionary (Language development and Guidance council, 2019) is an attempt to socialize something so that it becomes known by people. Ritcher (1987: 139) explains that socialization is a process to gain knowledge and skills carried out to play a role in society. According to Yeningwati (quoted in Anwar and Syafiqurrahman, 2016), taxation socialization is an activity carried out by DGT to increase public understanding and knowledge about tax. Attribution theory explains that individual behavior can be driven by external factors or circumstances which make them do a behavior. Tax socialization is an external factor that will build a good or bad image of tax collection on MSMEs. The tax sociali- 
zation will make MSMEs understand about "right" and "wrong" about taxation from others' insight, and finally, the moral perception is formed that it is right to behave tax obediently. Others can influence individual behavior in harmonizing with subjective norms variable in the TPB which explains that the belief to carry out behavior can be obtained from other's views of behavior. Awareness for tax compliance behavior can be instilled through others' education process, which will increase the ability and or readiness to comply with morality (Kwok and Yip, 2018). In line with the study, Mukhlis et al. (2015), Anwar and Syafiqurrahman (2016), as well as Wardani and Wati (2018) explain that if taxation socialization is carried out optimally and adequately, it will make MSMEs more compliant with their tax obligations. Therefore, socialization and assistance are expected by the MSMEs to get a more detailed explanation of taxation rules (Tatik, 2018). On the contrary, Cahyanti (2017) states that the taxation socialization and the financial condition of entrepreneurs do not affect the compliance of MSME taxpayers.

H2: Tax socialization has a positive effect on MSMEs tax compliance

\section{Accounting Knowledge in Moderating the Relationship between Taxation Under- standing and MSMEs Tax Compliance}

Understanding according to the Indonesian Dictionary (Language development and Guidance council, 2019a) is a process of understanding or makes someone understands. Accounting is a systematic system process to produce financial information that is needed for consideration of user decision-making (Herwiyanti, Azhar, Srirejeki and Dinanti, 2017:12). According to the American Institute of Certified Public Accountants (1961), accounting is an art in recording, classifying, and compiling an overview of financial events or transactions which are then presented in financial statements. Based on this definition, understanding accounting is how one can understand the process of making records, classifying, and summarizing financial transactions then present them in the financial statements. MSMEs, as one of the users of financial information, need an understanding of accounting to make them able to maintain stability and business decision making. The perception of the control variable in TPB explains that the belief in the realization of a behavior depends on how one's efforts can overcome difficulties when going to conduct a behavior. Following Ajzen's research (2012), this theory is relevant to describe behaviors that require planning, such as entrepreneurship. Recording or bookkeeping can be a factor that makes it easier to carry out tax obligations if the understanding of accounting is adequate. However, it is difficult if MSMEs' accounting knowledge is inadequate. MSMEs need simple financial accounting in calculating their monthly and annual turnover forms (Sudibyo et al., 2017).

The taxation understanding of MSME actors cannot be separated from the understanding of accounting in carrying out tax obligations in terms of the correctness of calculations, payments, and tax reporting. On the contrary, accounting knowledge alone is not adequate for MSMEs to meet the tax obligations without their understanding of tax. Tax calculation and reporting must be under applicable tax rules. If the MSMEs understand how to make records and or bookkeeping, it will facilitate them to calculate their tax debt. It is following the researches by Rusli, Hardi and Pakpahan (2015), Sumianto and Kurniawan (2015), Dartini and Jati (2016), and Darmawati and Oktaviani (2018) which explain that one's good understanding of accounting will facilitate him to calculate taxes following the rules rather than reporting taxes carelessly. In contrast, Safitri (2018) states another opinion that there is no need for MSMEs who have a turnover of below Rp4.8 billion to understand accounting to be able to carry out tax obligations.

H3: Accounting knowledge moderates the relationship between taxation understanding and MSMEs tax compliance

Accounting Knowledge in Moderating the Relationship between Taxation Socialization and MSMEs Tax Compliance

The perception of the control variable in TPB explains that the realization of a tax 
behavior depends on one's efforts in dealing with the level of difficulty in performing a behavior. Bookkeeping or recording requires a certain level of accounting knowledge. Accounting knowledge will affect the level of difficulty of the realization of the intention to perform tax-compliant behavior when they do not know what is explained by the tax officer. An adequate understanding of accounting will facilitate MSMEs to understands the information given by the tax authority, especially in the tax base sources used for calculations. If the information presented is fully understood by MSME actors, then they will adequately know data to use the tax base.

In developed countries like Hong Kong, the majority of MSME taxpayer respondents in the study agreed that the professional construct of understanding is useful in tax morale and tax compliance (Yücedoğru and Hasseldine, 2016). In this case, professionalism is to take proper records and report the records to a tax authority when needed. The professional attitude that MSMEs upheld in Hong Kong needs to be emulated because it will encourage them to prepare accurate reports. This will impact taxpayer confidence to comply with their tax obligations (Dartini and Jati, 2016). Taxpayer awareness can arise with a socialization strategy that is accompanied by coaching and mentoring (Bawono and Purnomo, 2016). The results of Sani and Habibie's research (2018) show that guidance and counseling as well as information dissemination on the importance of accounting in tax reporting and accounting training among taxpayers, especially MSMEs are needed to improve tax compliance. In contrast, Safitri (2018) states no need for MSMEs who have a turnover of below Rp4.8 billion to understand accounting. This caused MSMEs who have a turnover of below Rp4.8 billion only calculate tax based on gross income, so it is easier to understand without tax authorities' guidance.

H4: Accounting knowledge moderates the relationship between tax socialization and MSMEs tax compliance

\section{RESEARCH METHODS \\ Population dan Sample}

Respondents in this study were MSMEs engaged in the trade, hotel, and restaurant sectors registered to Department of Labor, Cooperatives, and SMEs in 2019. Those sectors were chosen because they have the highest number of other sectors and the main focus of the economy in the Banyumas Regency. The samples in this study were taken from MSMEs of 27 districts in Banyumas Regency, Central Java. Samples were selected using a stratified cluster sampling technique named elementary sampling technique by Yamane (1967) that is randomly selected from each region of the main sample subunits, which have been divided proportionally from the selected homogeneous subpopulations. The number of MSME population is 84,415 MSMEs. The subpopulation in this study uses MSMEs engaged in trade, hotel, and restaurant sectors with number 42,355 MSMEs spread across 27 sub-districts. The number of samples needed in the study after calculated through the Slovin formula is 100. But to anticipate the data not returning and the data cannot be processed, a total of 200 questionnaires were distributed to respondents. And sample for each district provides by a proportional amount that is already calculated with the number of subpopulations for each district divided with the amount number of subpopulations chosen multiplied by the number of distributed questionnaires. This sampling was chosen because large population and diverse MSMEs manager or owner backgrounds make each level of knowledge of them indistinguishable, the ownership of privacy tax numbers maintained by DGT so that they cannot be targeted purposively, to improve the accuracy of simple random techniques by reducing the heterogeneity this technique is chosen. Questionaire distributes directly to managers and owners in the place. But if there's no person in charge when the questionnaire is delivered, it will be given a maximum of one week to complete the questionnaire. This research took one month 18 days start from November 1 , 2019 to complete the distribution of all questionnaires. 


\section{Data collection}

This study uses a survey method by a questionnaire as a research instrument. The survey method is a method of collecting data by distributing questionnaires containing questions addressed to respondents (Hartono, 2013: 12). The questionnaire consists of closed questions assisted with some open questions for better explanation reason respondents choose statements provided by the author.

This research adopted TPB and attribution theory to explain research construct with different variables about tax compliance behavior. This research has independent variables of taxation understanding and socialization. There is also accounting knowledge as a moderating variable in this study. The accounting knowledge is used as a moderating variable in this research to figure out the outside factor from taxation that often makes MSMEs getting trouble to comply with tax obligations. Meanwhile, the dependent variable in this study is the tax compliance of MSMEs. The indicators used to measure tax understanding and socialization variables in this study were adopted from previous research by Wardani and Wati (2018). The indicators used to measure accounting knowledge variables were adopted from previous studies by Sani and Habibie (2018). On the other hand, the MSME tax compliance variable indicator in this study was adopted from Rahayu (2010:138) which was developed from the research by Sani and Habibie (2018).

The research questionnaire was distributed directly to respondents or indirectly. A total of 200 questionnaires were distributed randomly to trade, hotel, and restaurant MSMEs that were distributed in 27 sub-districts in Banyumas Regency. Of the 200 questionnaires distributed in 49 days from October 1, 2019 until November 18, 2019. From 200 questionnaires already distributed, 151 were returned and could be processed.

\section{Data analysis}

This study uses a multivariate analysis Structural Equation Modeling (SEM) analysis tool that can measure variables that cannot be measured directly while at the same time is able to calculate the magnitude of the error of the measurement model under the study (Sholihin and Ratmono 2013:3). Measurement-based on variance in SEM is called Partial Least Square (PLS). PLS is a strong analysis method because it does not assume that the data must be in a particular measurement scale (Ghazali, 2014:30). SEM-PLS data analysis is by confirming the measurement model (outer model) and then evaluating the structure of the model (inner model) (Kock, 2012). The WarpPLS version 3.0 application is used to help the data analysis process in this study.

\section{ANALYSIS AND DISCUSSION Respondent Statistics}

This research was conducted at MSMEs in 27 districts in Banyumas Regency, Central Java. The number of samples used in this study is 151 respondents of MSMEs obtained through stratified cluster sampling techniques (Table 1). Respondents of this study are MSMEs, owners, or managers at MSMEs.

Based on the returned and processed questionnaire, there is information on the characteristics of respondents grouped by age, sex, last level of education of the respondents, forms of business, business duration, annual turnover, business location,

Table 1.

Distribution of Questionnaires

\begin{tabular}{|c|c|c|c|}
\hline No. & Information & $\begin{array}{c}\text { Number of } \\
\text { Respondents }\end{array}$ & Percentage \\
\hline 1. & Number of questionnaires distributed & 200 & 100 \\
\hline 2. & $\begin{array}{l}\text { Number of questionnaires that did not re- } \\
\text { turn }\end{array}$ & (21) & $(10.50)$ \\
\hline 3. & $\begin{array}{l}\text { Number of questionnaires returned but } \\
\text { could not be processed }\end{array}$ & $(28)$ & $(14.00)$ \\
\hline \multicolumn{2}{|r|}{ Returned and processed questionnaires } & 151 & 75.50 \\
\hline
\end{tabular}


ownership of Tax ID number, and experience of paying income tax. Based on data collected on 151 questionnaires, it is known that the majority of MSMEs have reached the age of 36-45 years, namely 66 respondents and dominated by men, namely 101 respondents. The last level of education of respondents was dominated by high school/vocational school graduates with a total of 80 respondents. The majority of businesses of MSMEs are 120 individuals, and the majority of them still have a turnover of less than Rp300 million. The majority of respondents, with a total of 64 respondents, have been in business for 1-5 years. The majority of respondents already have a Tax ID number and have experience of paying income tax which is 124 respondents.

Based on the data from the returned and processed questionnaire from respondents with the description above, the description of respondents' answers is obtained as in table 2.

\section{PLS Test}

The PLS test consists of testing the outer and inner models. The outer model consists of reliability, convergent validity, and

Table 2.

Descriptive Statistics

\begin{tabular}{lccccc}
\hline Var. & N & Min. & Max. & Avg. & $\begin{array}{c}\text { Std. } \\
\text { Dev. }\end{array}$ \\
\hline PA & 151 & 1 & 5 & 3.966 & 0.792 \\
PP & 151 & 2 & 5 & 4.043 & 0.638 \\
SP & 151 & 2 & 5 & 4.073 & 0.621 \\
KP & 151 & 1 & 5 & 4.271 & 0.686 \\
\hline
\end{tabular}

PA: Accounting Knowledge; PP: Tax Understanding; SP: Tax Socialization; KP: MSME Tax Obedience discriminant validity. The inner model consists of testing the determination coefficient testing, predictive relevance, and size testing effect.

The validity test results in table 3 show all the output composite reliability values and Cronbach's Alpha variables of accounting knowledge, taxation understanding, tax socialization, and MSME tax compliance are above 0.60. In line with Nunnally and Bernstein's criteria in 1994, the research instrument used to measure the variables that construct this research model's construct has the right consistency (cited in Kock, 2012:56).

The convergent validity test results in this study showed that the entire loading indicator of each indicator on the variables of accounting knowledge, taxation understanding, tax socialization, and MSME tax compliance is above 0.70 . Indicators of this study have good convergent validity in line with Sholihin and Ratmono (2013:16), who states that the value of loading indicators above 0.70 has good convergent validity. Good or high convergent validity indicates that the set of indicators that have been used in this study represent one latent variable.

Table 3.

Composite Reliability and Cronbach's Alpha results

\begin{tabular}{lrrl}
\hline Var. & $\begin{array}{r}\text { Composite } \\
\text { Reliability }\end{array}$ & $\begin{array}{c}\text { Cronbach's } \\
\text { Alpha }\end{array}$ & Inform. \\
\hline PA & 0.965 & 0.960 & Reliable \\
PP & 0.972 & 0.967 & Reliable \\
SP & 0.980 & 0.976 & Reliable \\
KP & 0.926 & 0.907 & Reliable \\
PA*PP & 0.994 & 0.994 & Reliable \\
PA*SP & 0.993 & 0.993 & Reliable \\
\hline
\end{tabular}

Table 4.

Correlation Results of Latent Variables

\begin{tabular}{lrrrrrr}
\hline & PA & \multicolumn{1}{c}{ SP } & \multicolumn{1}{c}{ PP } & KP & PA*SP & PA*PP \\
\hline PA & $(0.858)$ & & & & & \\
SP & 0.035 & $(0.880)$ & & & & \\
PP & 0.500 & 0.021 & $(0.918)$ & & & \\
KP & 0.678 & 0.133 & 0.455 & $(0.802)$ & & \\
PA*SP & -0.380 & -0.163 & 0.067 & -0.404 & $(0.790)$ & \\
PA*PP & -0.270 & 0.067 & -0.477 & -0.298 & -0.126 & $(0.785)$ \\
\hline
\end{tabular}


Furthermore, the discriminant validity test results show that the AVE square value shown diagonally in Table 4 is greater than the other constructs' correlation. Then, all the results of loading indicators to the construct measured are greater than the results of loading on other constructs. In line with Fornell and Larcker (1981) regarding two conditions for fulfilling the discriminant validity of a construct, the research instrument already has adequate discriminant validity. The discriminant validity that is fulfilled indicates that the set of combined indicators is not unidimensional or does not contain just one type of symptom.

\section{Inner Model}

The structural model is used to describe the relationship among latent variables. Structural model testing can go through the determination test and the predictive relevance test which can be seen through $\mathrm{R}$ -squared and Q-squared which are presented in Table 5 and Table 6.

The results of the coefficient of determination in Table 5 show the R-squared value of 0.648 . The coefficient of determination of 0.648 indicates an independent variation of taxation understanding and socialization as well as a moderating variable in accounting knowledge that is able to explain $64.7 \%$ of the variation of the MSME tax compliance variable. This amount percentage includes a strong research construct (Sholihin \& Ratmono, 2013). Meanwhile, the predictive relevance output results listed in Table 5 show a value of 0.582 , which indicates that this research model has predictive relevance because the Q-squared value has a value of more than zero.

Table 5.

Results of Determination Coefficients and Predictive Relevance of Research

\begin{tabular}{|c|c|c|c|c|c|c|}
\hline & PA & SP & PP & KP & $\mathbf{P A} * \mathbf{S P}$ & $P A * P P$ \\
\hline$R^{2}$ & & & & 0.6 & & \\
\hline$Q^{2}$ & & & & 0.5 & & \\
\hline
\end{tabular}

The results of the moderation effect size in Table 6 show that accounting knowledge variables have an influence of 0.130 in moderating the relationship between taxation understanding and MSME tax compliance. Meanwhile, the moderating effect size of the accounting knowledge variable has an influence of 0.036 in moderating the relationship between tax socialization and MSME tax compliance. According to Sholihin and Ratmono (2013:16), the size of the effect of the variable of accounting knowledge of 0.021-0.150 in moderating the relationship between tax socialization and MSME tax compliance has moderate strength.

\section{Hypothesis Test Result and Discussion}

Path analysis is used to calculate the influence of accounting knowledge variables in influencing the independent variables of taxation understanding and socialization on the MSME tax compliance dependent variable. The results of the analysis of the respondent data path processed by WarpPLS summarized in Figure 1.

\section{The Influence of Tax Understanding on MSME Tax Compliance}

The results of the calculation of the path

Figure 1.

Overall Variable Relationship Structure

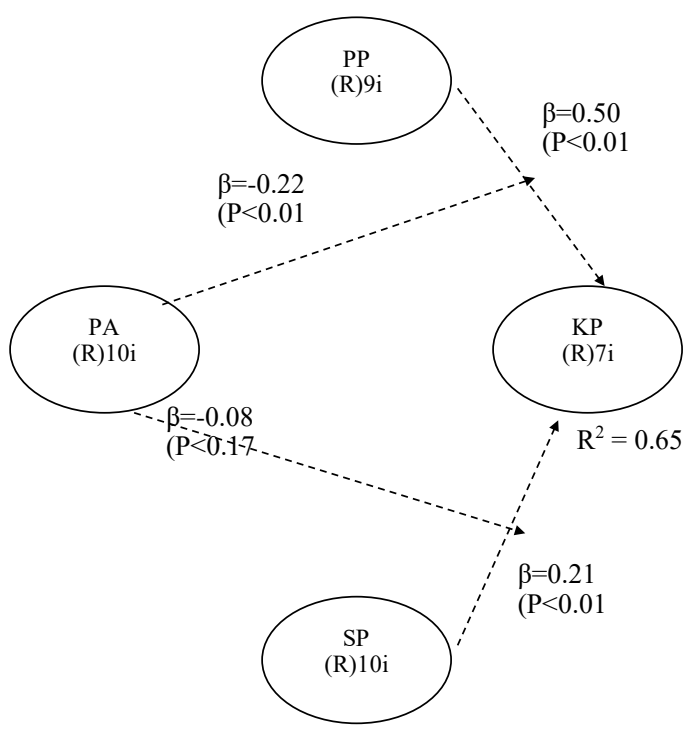

Table 6.

Results of Moderation Effect Sizes

\begin{tabular}{|c|c|c|c|c|c|}
\hline & PA & PP & KP & $\mathbf{P A} * \mathbf{P P}$ & PA*SP \\
\hline KP & & 0.364 & 0.117 & 0.130 & 0.036 \\
\hline
\end{tabular}


coefficient show that the tax understanding $(\mathrm{PP})$ variable to the tax obedience $(\mathrm{KP})$ variable has a value of 0.496 with a positive result and has a significance of $<0.001$. Understanding tax matters could make someone do a certain assessment of the consequences of doing a behavior to comply with tax obligations. The consequence of this tax evaluation triggers taxpayers, especially MSMEs to conduct a certain behavior about tax. The MSME's shallow understanding regarding the system of taxation working makes many MSMEs do not understand the benefits they receive from taxation. This lack of understanding of tax knowledge will make MSMEs consider that compliance with tax obligations will not beneficial for them in the future time so that there are still many who deliberately ignore their tax obligations. The results of this study are in line with the results of the research by Mukhlis et al. (2015) which states that a higher level of tax knowledge will make people aware of their tax obligations. Then it is also supported by the results of the study by Oladipupo and Obazee (2016), Anwar and Syafiqurrahman (2016), as well as Wardani and Wati (2018) which state that a high level of tax understanding will increase tax compliance of MSMEs.

\section{The Influence of Tax Socialization on MSME Tax Compliance}

The results of the path coefficient calculation show that the tax socialization (SP) variable against the tax compliance (KP) variable has a value of 0.214 with a positive result and a significance of 0.003 . This result proves tax socialization makes MSMEs understand "right" and "wrong" about tax from the view of others, and finally, the moral perception is formed that it is right to behave tax obediently. Individual behavior can be influenced by others under subjective norms in the TPB which explains that the belief to carry out behavior can be obtained from other's views of behavior. Awareness for tax compliance behavior can be instilled through the education process of others, which will increase the ability and or readiness to comply with morality (Kwok and Yip, 2018). This research is in line with the research by Kwok and Yip
(2018) which states that the awareness to conduct tax compliance behavior can be instilled through the education process of others, which will increase the ability and or readiness to comply with morality behave in tax compliance. The same thing was stated in the research by Mukhlis et al. (2015), Anwar and Syafiqurrahman (2016), as well as Wardani and Wati (2018) who explain that if taxation socialization is carried out optimally and adequately, it will make MSMEs more compliant with their tax obligations.

\section{The Influence of Accounting Knowledge in Moderating the Relationship between Taxation Understanding and MSME Tax Compliance}

The results of the calculation of the path coefficient show that the relationship between the $\mathrm{PA} * \mathrm{PP}$ variable and the KP variable has a value of 0.223 with a negative result and a significance of 0.002 . Adverse effects indicate that accounting knowledge tends to weaken the relationship between taxation understanding and MSME tax compliance. Many MSMEs have tried to record using either the application or conventional methods. However, from the application of recording, especially the manual one, many have not done the recording properly. Following the statement of Sudibyo and Jianfu (2016) which explains private-owned businesses do not have a more stable relationship than stateowned businesses in their expertise in managing taxes according to the tax authority's provisions. The existing concept of self-assessment and payments which are partly not confirmed by tax officials, makes many MSMEs still make their report improperly and do not match the actual turnover. The answer to one open question in this research shows almost all MSMEs know how important tax to development in this country, but they answer not feel the benefit of tax, especially in micro and small business respondents. Some of them feel a tax burden on their financial and business development. Some of MSMEs that already hold recording and bookkeeping, even more, use Public Law 23 the Year 2018 to do tax obligation said it is not right to col- 
lect tax from MSMEs, it is hard to develop a sturdy foundation in the business world if have to minimize their expenditure operational budget funds for payment of tax. In here, the more accounting knowledge owned by MSMEs manager or owner would make them more understand if paid the tax would reduce their business profit. This is especially when the tax base is charged to gross income that has not been reduced by costs. The more accounting information obtained and known by MSMEs would make their manager or owner think twice about doing tax obligations because this concerns the sustainability of the business in the future head. MSMEs would understand their tax obligations as good citizens when justices about the attention given and substantial tax benefits can be provided by the government directly experience by MSMEs (Mukhlis et al., 2015). It is also important to consider the perceived fairness of tax when it involves the intention of each taxpayer to do compliance. Even so, accounting knowledge plays an important role as MSMEs do their planning to reduce the amount of tax payment. The MSMEs' accounting knowledge must also be balanced with better control if DGT wants to improve the MSMEs tax compliance. Accounting knowledge is needed for MSMEs to calculate tax. It is in line with the statement in the study by Sudibyo et al. (2017) which states that simple financial accounting is needed by MSMEs in calculating both monthly and annual turnover. If the SMEs understand how to make records and or bookkeeping, then it will facilitate them to calculate their tax. Rusli et al. (2015), Sumianto and Kurniawan (2015), Dartini and Jati (2016), and Darmawati and Oktaviani (2018) explained that a good understanding of accounting would facilitate the calculation of taxes under the rules, reporting taxes correctly. Previous studies explain the direct relationship between accounting knowledge and MSME tax compliance in contrast to this study which proves accounting knowledge a moderating variable for MSME tax compliance. Accounting knowledge here comes as consid- eration for MSMEs to do their tax obligations.

\section{The Influence of Accounting Knowledge in Moderating the Relationship between Tax Socialization and Tax Compliance of MSMES}

The results of the calculation of the path coefficient show that the $\mathrm{PA} * \mathrm{SP}$ variable to $\mathrm{KP}$ variable has a value of 0.078 with a negative result and a significance of 0.166. The insignificant result was because Banyumas Regency has a wide area causing the direct distribution of information and notices of tax is not optimum, especially to the area out of the city center. The limited number of tax officers compared to the number of MSMEs that continue to increase each year, as well as the wide-area coverage for one tax office (KPP) cause direct socialization not to run accordingly. Second, MSMEs prefer two directions interactive media rather than one direction one. However, the local tax authorities have tried actively on social media, some MSMEs state that the response is still not optimal. This is in line with the statement in Tatik's research (2018), which states that MSMEs expect socialization accompanied by assistance to get more detailed information related to tax regulations. More detailed information is needed considering that the MSMEs have to calculate their taxes on income. The socialization strategy accompanied by coaching and mentoring will raise awareness of taxpayers (Bawono and Purnomo, 2016). Intensive guidance and assistance regarding tax calculation and reporting will further motivate MSME actors to carry out tax obligations. Previous studies explain the direct relationship between accounting Knowledge and MSME tax compliance in contrast to this study which makes accounting knowledge a moderating variable for MSME tax compliance. The negative path shows in this research result indicate higher accounting knowledge has the potential to reduce the effect of tax socialization on MSMEs' compliance with tax obligations. This can be caused by the more each MSME has accounting knowledge would make 
them know calculate tax from gross income would significantly reduce the net income that can be obtained. This would grow antipathy and passive response to tax socialization then indifference for taxation.

\section{CONCLUSION}

The results of this study show that taxation understanding, tax socialization, and accounting knowledge in moderating taxation understanding have a partial effect on MSME tax compliance in Banyumas Regency. Taxation understanding and promotion have a positive effect on MSME tax compliance. Accounting knowledge influences the taxation understanding but has the effect of weakening the relationship between taxation understanding and MSME tax compliance. On the other hand, accounting knowledge is proven not to affect the relationship between tax socialization and MSME tax compliance.

As an implication of this study, the researcher suggests that MSME insight for tax in Banyumas Regency needs improvement to make them more compliant in carrying out tax obligations in the future. Tax insights can be obtained from various easily accessed strategic media. The tax authorities, especially in Banyumas Regency, should be more open about the information on tax revenue from the public and be more communicative towards MSMEs. Social media, locally printed media, or television can become the media that can reach local people. Furthermore, an applicable and intensive training program in calculating taxes for MSME actors needs to be held by the tax authority in Banyumas Regency. Training is needed because not all MSMEs can learn taxation issues independently because of the lack of MSME educational background in finance.

\section{LIMITATIONS AND SUGGESTIONS}

This study has limitations. Not all MSME scales and business forms can be examined in this study. MSMEs in institute form and already in medium scales have more complex structures and are closed from individual forms. The more complex structural complexity causes researchers to not able to distribute questionnaires directly to several MSMEs, this makes respondents were not supervised by authors while filling out the questionnaire. The questionnaire that is not supervised by authors directly improves the probability questionnaire filled out by other partiesthat are not related to the vital person related to this study. Future studies are expected to be able to distribute questionnaires with different procedures. Questionnaires can be distributed in a meeting forum attended by MSMEs and are taken at that time. After gathering data from respondents, it is found from the answer of an open question directed to respondents that other important factors such as the sustainability of MSMEs and perceived fairness can be affected consi deration of MSMEs paying a tax. In the next study, it could be better if it considers sustainability and fairness factors to develop this research model.

\section{REFERENCES}

Ajzen, I. (1991). The theory of planned behavior. Organizational Behavior and Human Decision Processes.

Ajzen, I. (2012). The theory of planned behavior. In Handbook of Theories of Social Psychology: Volume 1.

Akbar, R.N. (2015). Pengaruh pemahaman, kualitas pelayanan, sanksi perpajakan terhadap kepatuhan wajib pajak Usaha Mikro Kecil dan Menengah (UMKM) (Studi kasus pada UMKM di Kota Malang). Universitas Brawijaya.

Anwar, R.A., \& Syafiqurrahman, M. (2016). Pengaruh sosialisasi perpajakan terhadap kepatuhan perpajakan wajib pajak Usaha Mikro Kecil dan Menengah (UMKM) di Surakarta dengan pengetahuan perpajakan sebagai variabel pemediasi. InFestasi, 12(1), 6674.

Bawono, I.R., \& Purnomo, R. (2016). Model Keefektifan Strategi dan Metode Sosialisasi untuk Meningkatkan Kesadaran dan Kepatuhan Pajak UMKM. Purwokerto: Unsoed Press.

Cahyanti, M.D. (2017). Pengaruh sosialisasi perpajakan, kualitas pelayanan fiskus, dan kondisi keuangan pengusaha terhadap kepatuhan wajib pajak Usaha Mikro Kecil Menengah (UMKM) di Kabupaten Magetan (Studi 
pada UMKM di Sentra Industri Penyamak Kulit Magetan). Universitas Muhammadiyah Ponorogo.

Darmawati, D., \& Oktaviani, A.A. (2018). Pengaruh penerapan akuntansi umkm terhadap kepatuhan wajib pajak UMKM e-commerce. Paper dipresentasikan pada acara Seminar Nasional Cendikiawan.

Dartini, G.S., \& Jati, I. (2016). Pemahaman akuntansi, transparasi, dan akuntabilitas pada kepatuhan wajib pajak badan. E-Jurnal Akuntansi Universitas Udayana, 17(3), 2447-2473.

Ghazali, I. (2014). Structural Equation Modeling, metode alternatif dengan Partial Least Square (PLS) (Edisi 4). Semarang: Badan Penerbit Universitas Diponegoro.

Hartono, J. (2013). Metodologi penelitian bisnis salah kaprah dan pengalamanpengalaman. Edisi 6. Yogyakarta: BPFE.

Herwiyanti, E., Azhar, S., Srirejeki, K., \& Dinanti, A. (2017). Akuntansi UMKM (Cetakan 1; R. Permana, Ed.). Semarang: Saraswati Nitisara.

Kock, N. (2012). WarpPLS 3.0 User Manual. In WarpPLS 3.0 User Manual.

Kusuma, H. (2018). Dilema UMKM, antara tarif pajak murah dan wajib pembukuan. Retrieved February 4, 2020, from Detik Finance Online website: https://www.finance.detik.com/

Kwok, B.Y.S., \& Yip, R.W.Y. (2018). Is tax education good or evil for boosting tax compliance? Evidence from Hong Kong. Asian Economic Journal, 32(4), 359-386.

Language development and Guidance council. (2019a). Paham. Retrieved September 2, 2019, from Kamus Besar Bahasa Indonesia website: https:// kbbi.kemdikbud.go.id/

Language development and Guidance council. (2019b). Sosialisasi. Retrieved September 2, 2019, from Kamus Besar Bahasa Indonesia website: https:// kbbi.kemdikbud.go.id/

Ministry of Cooperatives and Small and Medium Enterprises. (2020a). Perkembangan data Usaha Mikro, Kecil dan Menengah (UMKM) dan Usaha Besar (UB) Tahun 2010-2015. Retrieved March 3, 2020, from http:// www.depkop.go.id/

Ministry of Cooperatives and Small and Medium Enterprises. (2020b). Perkembangan data Usaha Mikro, Kecil dan Menengah (UMKM) dan Usaha Besar (UB) Tahun 2015-2016. Retrieved
March 3, 2020, from http:// www.depkop.go.id/.

Ministry of Cooperatives and Small and Medium Enterprises. (2020c). Perkembangan data Usaha Mikro, Kecil dan Menengah (UMKM) dan Usaha Besar (UB) Tahun 2016-2017. Retrieved March 3, 2020, from http:// www.depkop.go.id/.

Ministry of Cooperatives and Small and Medium Enterprises. (2020d). Perkembangan data Usaha Mikro, Kecil dan Menengah (UMKM) dan Usaha Besar (UB) Tahun 2017-2018. Retrieved March 3, 2020, from http:// www.depkop.go.id/.

Ministry of Finance. (2019). Ini capaian $A P B N$ 2018. Retrieved September 2, 2019 , from ht ps:// www.kemenkeu.go.id/

Mukhlis, I., Utomo, S.H., \& Soesetio, Y. (2015). The role of taxation education on taxation knowledge and its effect on tax fairness as well as tax compliance on handicraft SMEs Sectors in Indonesia. International Journal of Financial Research.

Noor, A.F. (2018). Pemerintah perlu dukung pengembangan UMKM. Retrieved February 8, 2020, from https:// www.republika.co.id/

Oladipupo, A.O., \& Obazee, U. (2016). Tax knowledge, penalties and tax compliance in Small and Medium Scale Enterprises in Nigeria. IBusiness.

Rahayu, S.K. (2010). Perpajakan Indonesia: Konsep dan aspek formal. Yogyakarta: Graha Ilmu.

Republic of Indonesia. Law Number 36 Year 2008 concerning Income Tax. (2008).

Republic of Indonesia. Government Regulation No. 23 Year 2018 concerning Income Tax On Income From Business Received Or Earned By Taxpayer Having Certain Gross Turnover. (2018).

Ritcher, J.R. (1987). An econometric analysis of income tax evasion and its detection. The RAND Journal of Economics, 22, 14-35.

Rusli, R., Hardi, H., \& Pakpahan, Y. (2015). Pengaruh pemahaman akuntansi, pemahaman ketentuan perpajakan dan transparansi dalam pajak terhadap kepatuhan wajib pajak badan. Jurnal Online Mahasiswa Fakultas Ekonomi Universitas Riau, 2(2), 1-15.

Safitri, N. (2018). Pengaruh pemahaman akuntansi dan perpajakan serta demografi terhadap kepatuhan wajib 
pajak usahawan. STIE Perbanas Surabaya.

Sani, A., \& Habibie, A. (2018). Pengaruh moral wajib pajak, sikap wajib pajak dan norma subjektif terhadap kepatuhan pajak melalui pemahaman akuntansi. Jurnal Ilman, 5(2), 80-96.

Sholihin, M., \& Ratmono, D. (2013). Analisis SEM-PLS dengan WrapPLS 3.0 untuk hubungan nonlikier dalam penelitian sosial dan bisnis. Yogyakarta: Penerbit Andi.

Suara Merdeka. (2018). Banyumas berperan di sektor perdagangan. Retrieved January 30, 2020, from Suara Merdeka Online website: https:// www.suaramerdeka.com/

Sudibyo, Y.A., \& Jianfu, S. (2016). Political connections, state owned enterprises, and tax avoidance: An evidence from Indonesia. Corporate Ownership and Control, 13(3), 279-283.

Sudibyo, Y.A., Purnomo, R., \& Bawono, I.R. (2017). Model optimalisasi peran tax centre UNSOED sebagai konsultan pajak untuk Usaha Kecil Mikro dan Menengah. Prosiding Seminar Nasional dan Call of Papers Pengembangan Sumber Daya Pedesaan dan Kearifan Lokal Berkelanjutan VII.

Sumianto, \& Kurniawan, C.H.H. (2015). Pengaruh pemahaman akuntansi dan ketentuan perpajakan serta transparansi dalam pajak terhadap kepatuhan wajib pajak orang pribadi usahawan pada UKM di Yogyakarta. MODUS, 27(1), 41-51.

Tatik. (2018). Potensi kepatuhan pembayaran pajak pada pelaku UMKM (Usaha Mikro Kecil dan Menengah) pasca penerbitan Peraturan Pemerintah Nomor 23 Tahun 2018. Paper dipresentasikan pada acara Seminar Nasional dan Call for Paper Sustainable Competitive Advantage (SCA) 8.

Wardani, D.K., \& Wati, E. (2018). Pengaruh sosialisasi perpajakan terhadap kepatuhan wajib pajak dengan pengetahuan perpajakan sebagai variabel intervening (Studi pada wajib pajak orang pribadi di KPP Pratama Kebumen). Nominal, Barometer Riset Akuntansi dan Manajemen, 7(1), 3354.

Yamane, T. (1967). Elementery Sampling Theory. U.S. America: Prentice Hall.

Yucedogru, R., \& Hasseldine, J. (2016). Understanding tax morale of SMEs: A qualitative study. EJournal of Tax Research, 14(3), 531-566. 